\title{
Gambaran Klinis Ketoasidosis Diabetikum Anak
}

\section{Clinical Profile of Children with Diabetic Ketoacidosis}

\author{
Haryudi Aji C \\ Laboratorium IImu Kesehatan Anak Rumah Sakit Dr. Saiful Anwar Malang
}

\begin{abstract}
ABSTRAK
Penelitian ini dilakukan untuk menggambarkan profil klinis ketoasidosis diabetikum pada anak. Data dikumpulkan dari rekam medik gambaran klinis pasien ketoasidosis diabetikum yang didapatkan di Bagian Anak Rumah Sakit dr. Saiful Anwar Malang pada tahun 2005-2009. Pada masa penelitian ini didapatkan 19 pasien dengan usia 1-14 tahun dengan proporsi 58\% perempuan, 53\% berusia antara 5-10 tahun dan 63\% mengalami gizi kurang. Pada 53\% pasien memberikan gambaran konsentrasi bikarbonat pada darah sebesar 5-9,9 mmol/L. osmolaritas darah >295-400 mOsm/l ditemukan pada $84 \%$ pasien dan $53 \%$ pasien mempunyai level potasium 3,5-5 mmol/L dan $42 \%$ pasien mempunyai kadar leukosit 10.000-<20.000/ul. Keluhan yang paling banyak ditemukan pada pasien adalah muntah, nyeri perut, penurunan kesadaran, kejang, diare, penurunan berat badan, polyuria, polydipsia, polyphagi dan demam. Keluhan terbanyak adalah polyuria yang didapatkan pada $16 \%$ kasus. Sebagian besar (67\%) penderita Ketoasidosis Diabetikum anak mempunyai kadar keton lebih dari $5 \mathrm{mmol} / \mathrm{I}$ dan $61 \%$ mengalami ketonuri (4+) serta 63\% pasien mempunyai anion gap 12.0-24.0.
\end{abstract}

Kata Kunci: Anak, gambaran klinis, ketoasidosis diabetikeum

\section{ABSTRACT}

The goal of this research was to describe clinical profile of diabetic ketoacidosis in children. A descriptive study was performed in 19 patients, 1-14 years of age, diagnosed in Pediatric Department of Saiful Anwar Hospital between 2005 and 2009. From the 19 patients 58\% were girls. 53\% were between 5 and 10 years of age. $63 \%$ were undernourished. About $53 \%$ had moderate Diabetic Ketoacidosis. 53\% patients had blood bicarbonate concentrations of 5-9,9 mmol/L. Blood osmolarity levels of $>295-400 \mathrm{mOsm} / \mathrm{l}$ in $84 \%$ patients. $53 \%$ had blood potassium levels of 3,5-5 mmol/L. $42 \%$ patients had leucocyte counts of 10.000-<20.000/ul. The most common symptoms of those patients were vomiting, abdominal pain, decreased of consciousness, seizures, diarrhea, decreased of body weight, polyuria, polydipsia, polyphagi and febris. The majority complaints was polyuria (16\%). The majority patients (67\%) of Diabetic Ketoacidosis had blood ketone levels more than $5 \mathrm{mmol} / \mathrm{l}$ and $61 \%$ had ketonuri (4+) and 63\% patients had anion gap levels about 12.0-24.0.

Keywords: Children, clinical profile, diabetic ketoacidosis

Jurnal Kedokteran Brawijaya, Vol. 27, No. 2, Agustus 2012; Korespondensi: Haryudi Aji C. Laboratorium Ilmu Kesehatan Anak, Rumah Sakit Umum Dr. Saiful Anwar Malang, Jl. Jaksa Agung Suprapto No.2 Tel. (0341)343343 Email:haryudi_aji2000@yahoo.com 


\section{PENDAHULUAN}

Ketoasidosis diabetik (KAD) disebabkan oleh penurunan insulin efektif di sirkulasi yang disertai peningkatan hormon regulator kontra seperti glukagon, katekolamin, kortisol, dan hormon pertumbuhan. Hal ini menyebabkan peningkatan produksi glukosa oleh hati dan ginjal, serta gangguan penggunaan glukosa perifer dengan akibati hiperglikemia dan hiperosmolalitas. Peningkatan lipolisis, disertai produksi benda keton (beta-hidroksibutirat, asetoasetat), menyebabkan ketonemia dan asidosis metabolik. Hiperglikemia dan asidosis menyebabkan diuresis osmotik, dan hilangnya elektrolit. Kriteria biokimia untuk diagnosis KAD meliputi hiperglikemia (kadar glukosa $>11 \mathrm{mmol} / \mathrm{L}(>200 \mathrm{mg} / \mathrm{dL}$ )) disertai $\mathrm{pH}$ vena $<7,3$ dan/atau bikarbonat $<15 \mathrm{mmol} / \mathrm{L}$. Terdapat juga glukosuria, ketonuria dan ketonemia $(1,2)$.

Ketoasidosis diabetik adalah penyebab utama kesakitan dan kematian pada anak penderita diabetes mellitus tipe 1 (DMT1). Mortalitas terutama berhubungan dengan terjadinya edema serebri (menyebabkan 57\%-87\% dari seluruh kematian karena KAD). Angka kematian akibat KAD di Amerika Serikat adalah 1\%-3\%. Frekuensi KAD sendiri bervariasi antar negara, berkisar antara 15\% dan $67 \%$ di Eropa dan Amerika Utara dan dapat lebih sering di negara negara sedang berkembang. KAD sering terjadi sebaga i presentasi klinis awal pasien DMT1, namun tidak jarang pula terjadi pada pasien yang sudah terdiagnosis DMT1. Pada pasien DMT1, KAD terjadi umumnya akibat tidak diberikannya suntikan insulin (sering akibat depresi atau karena masalah biaya) atau karena terapi insulin yang tidak adekuat pada masa sakit/trauma (3).

KAD dapat terjadi pada saat diagnosis maupun pada penderita lama. KAD berulang terjadi bila pemberian insulin tidak teratur, sering karena tidak diberikan. Pada anak remaja, ketoasidosis diabetes hampir selalu dikarenakan ketidak-patuhan pemberian insulin. Namun dapat pula terjadi sebagai akibat sedang menderita sakit lain pada penderita diabetes, misalnya diare, infeksi dll. Tatalaksana KAD meliputi koreksi hiperglikemia, dehidrasi dan gangguan elektrolit dengan cairan dan insulin intravena. Monitoring klinik dan laboratorium yang ketat serta observasi penderita secara individual adalah sangat penting untuk memberikan penanganan yang optimal $(3,4)$.

Gambaran klinis penderita KAD sangat bervariasi. Beragamnya gambaran klinis ini sering mengaburkan diagnosis KAD sehingga akan mengakibatkan penanganan KAD yang kurang optimal bahkan menyebabkan kematian $(4,5)$. Penelitian ini menggambarkan secara klinis pasien KAD di RSSA antara tahun 2005-2009. Hasil penelitian diharapkan dapat menjadi dasar dalam mengembangkan kriteria diagnosis Ketoasidosis Diabetes.

\section{METODE}

Penelitian ini bersifat deskriptif retrospektif. Sampel diambil dari semua pasien KAD yang berobat ke bagian Ilmu Kesehatan Anak-Rumah Sakit dr. Saiful Anwar antara tahun 2005-2009. Karakteristik yang dikaji meliputi data umum yaitu usia dan jenis kelamin, gambaran klinis yaitu status gizi, keluhan klinis serta profile metabolik dari hari pemeriksaan laboratorium. Data dianalisa secara deskriptif dan disajikan dalam bentuk tabulasi.

\section{HASIL}

Gambaran seluruh sampel penelitian antara tahun 20052009 berjumlah 19 catatan medis pasien KAD. Jumlah umum pasien KAD RSSA dalam 5 tahun (2005-2009) menunjukkan gambaran peningkatan. Keseluruhan pasien berasal dari wilayah Malang Raya. Distribusi pasien berdasarkan jenis kelamin digambarkan dalam Tabel 1 dan didapatkan pasien laki-laki lebih sedikit (36,8\%) dibandingkan dengan pasien perempuan sebesar 12 (63,2\%). Usia paling banyak didapatkan pada usia diatas 5 tahun dimana ada dua kelompok usia yaitu 5-10 tahun sebanyak 9 pasien dan lebih dari 10 tahun 8 pasien. Keluhan yang tercatat pada pendetia KAD di RSSA sangat bervariasi, meliputi gejala klasik DM berupa poliuria (74\%), polidipsi (63\%), polifagi (58\%) (biasanya tidak tampak pada anak dan sering anak tidak mau makan), mual- muntah $(58 \%)$, nyeri perut $(63 \%)$ serta penurunan berat badan $(42 \%)$.

Tabel 1. Karakteristik penderita KAD di RSSA

\begin{tabular}{|c|c|c|}
\hline Keterangan & Jumlah & (\%) \\
\hline \multicolumn{3}{|l|}{ Jenis Kelamin: } \\
\hline Laki-laki & 7 & $(38,8)$ \\
\hline Perempuan & 12 & $(62,2)$ \\
\hline \multicolumn{3}{|l|}{ Usia: } \\
\hline$<5$ tahun & 2 & \\
\hline 5-10 tahun & 9 & \\
\hline$>10$ tahun & 8 & \\
\hline \multicolumn{3}{|l|}{ Staus Gizi: } \\
\hline Gizi buruk & 1 & $(5,3)$ \\
\hline Gizi kurang & 15 & $(78,9)$ \\
\hline Gizi baik & 1 & $(5,3)$ \\
\hline Gizi lebih & 2 & $(10,5)$ \\
\hline Obesitas & 0 & (0) \\
\hline \multicolumn{3}{|l|}{ Gambaran Klinis: } \\
\hline Muntah & 11 & (58) \\
\hline Nyeri perut & 12 & (63) \\
\hline Penurunan kesadaran & 12 & (63) \\
\hline Kejang & 1 & $(5,3)$ \\
\hline Diare & 1 & $(5,3)$ \\
\hline Penurunan BB & 8 & $(42)$ \\
\hline Poliuria & 14 & (74) \\
\hline Polidipsia & 12 & (63) \\
\hline Polifagia & 11 & (58) \\
\hline Demam & 8 & (42) \\
\hline
\end{tabular}

Profil metabolik penderita menunjukkan semua penderita KAD yang dirawat di RSSA mengalami gangguan keseimbangan cairan dan elektrolit. Semua pasien KAD di RSSA mengalami asidosis dan sebagian besar (90\%) dengan kadar $\mathrm{HCO} 3$ diabawah $15 \mathrm{mmol} / \mathrm{L}$. Anion gap terjadi pada sebagian besar penderita KAD di RSSA (90\%). Demikian juga kadar keton darah naik pada semua pasien KAD. Sebagian besar pasien KAD di RSSA mengalami hiperosmolaritas dengan kadar osmolaritas lebih dari 295 mOSm/L (84,2\%). Kadar natrium dan kalium pada penderita KAD cukup bervariasi meskipun hampir separo berada pada kisaran normal. Kadar lekosit pada penderita KAD anak didapatkan sebagian besar $(84,2 \%)$ meningkat 
$(>10.000)$.

Tabel 2. Profil Metabolik Penderita KAD di RSSA

\begin{tabular}{|c|c|c|}
\hline Keterangan & Jumlah & (\%) \\
\hline \multicolumn{3}{|c|}{ Bikarbonat (mmol/L): } \\
\hline Tidak di cek & 1 & $(5,3)$ \\
\hline$<5$ & 3 & $(15,8)$ \\
\hline $5-9,9$ & 10 & $(52,6)$ \\
\hline $10-14,9$ & 4 & $(21)$ \\
\hline$>15$ & 1 & $(5,3)$ \\
\hline \multicolumn{3}{|l|}{ Anion GAP: } \\
\hline Tidak di cek & 1 & $(5,3)$ \\
\hline$<12$ & 1 & $(5,3)$ \\
\hline $12-15$ & 6 & $(31,6)$ \\
\hline $16-20$ & 3 & $(15,8)$ \\
\hline $21-24$ & 3 & $(15,8)$ \\
\hline $25-28$ & 5 & $(26,2)$ \\
\hline$>28$ & 0 & (0) \\
\hline \multicolumn{3}{|c|}{ Keton Darah (mg/dL): } \\
\hline$<3$ & 1 & \\
\hline $3-5$ & 6 & \\
\hline$>5$ & 13 & \\
\hline \multicolumn{3}{|c|}{ Osmolaritas (mOsm/L): } \\
\hline$<285$ & 0 & (0) \\
\hline $285-295$ & 0 & (0) \\
\hline $295-400$ & 16 & $(84,2)$ \\
\hline$>400$ & 3 & $(15,8)$ \\
\hline \multicolumn{3}{|c|}{ Natrium (mEq/L): } \\
\hline$<135$ & 5 & $(26,3)$ \\
\hline $135-145$ & 9 & $(47,4)$ \\
\hline$>145$ & 5 & $(26,3)$ \\
\hline \multicolumn{3}{|l|}{ Kalium (mEq/L): } \\
\hline$<3,5$ & 4 & $(21,1)$ \\
\hline $3,5-5$ & 10 & $(52,6)$ \\
\hline$>5$ & 5 & $(26,3)$ \\
\hline \multicolumn{3}{|l|}{ Leukosit (u/L): } \\
\hline$<10.000$ & 3 & $(15,8)$ \\
\hline $10.000-20.000$ & 7 & $(36,8)$ \\
\hline $20.000-30.000$ & 4 & $(21,1)$ \\
\hline$>30.000$ & 5 & $(26,3)$ \\
\hline
\end{tabular}

\section{PEMBAHASAN}

Hasil penelitian ini menunjukkan penderita terbanyak pada kelompok usia diatas 5 tahun dikarenakan pada usia ini didapatkan pertama kali serangan KAD dan kepatuhan untuk pemakaian insulin cukup rendah. Untuk itu diperlukan edukasi ke pasien, orang tua maupun lingkungan sekitar pasien agar dapat mendukung penanganan terapi secara komprehensif $(2,6,7)$. Pencegahan serangan KAD sangat diperlukan dengan melakukan penanganan terapi DM tipe 1 secara baik. Ada 5 hal yang harus dilakukan dalam menangani atau mencegah timbulnya KAD yaitu: pemberian Insulin, diet, olah raga, monitoring gula darah dan edukasi $(3,8,9)$.

Sebagian besar pasien KAD yang datang dalam keadaan gizi kurang, hal ini disebabkan sebagian besar pasien KAD merupakan pasien serangan pertama kali terjadi atau baru menderita DM tipe 1 yang mengalami serangan pertama KAD. Pasien baru ini biasanya mengalami keluhan lebih kurang 2 bulan sebelum serangan KAD, keluhan berupa polifagi, poliuri, polidipsi, berat badan turun. Penurunan berat badan ini menyebabkan terjadinya gizi kurang $(10,11)$.

Muntah pada pasien KAD disebabkan karena asidosis metabolik, sedangkan nyeri perut terjadi akibat menurunnya perfusi mesenterium, dehidrasi otot dan jaringan usus serta paralisis saluran cerna akibat gangguan keseimbangan asam basa dan elektrolit. Muntah dan nyeri perut ini sering menyebabkan terjadinya salah diagnosis saat awal pasien datang $(3,12)$.

Prinsip tata laksana KAD meliputi terapi cairan untuk mengkoreksi dehidrasi dan menstabilkan fungsi sirkulasi, pemberian insulin untuk menghentikan produksi badan keton yang berlebihan, mengatasi gangguan keseimbangan elektrolit, mengatasi faktor presipitasi atau penyakit yang mendasari KAD serta monitor komplikasi terapi $(7,13,14)$. Salah satu faktor keberhasilan terapi KAD adalah rehidrasi yang adekuat. Tujuan rehidrasi adalah untuk memperbaiki sirkulasi, menurunkan kadar hormon counter regulatory, menurunkan kadar gula darah dan memperbaiki perfusi ginjal.

Terdapat 19 penderita KAD sebagian besar KAD tipe moderate, memiliki konsentrasi bikarbonat 5-9,9 mmol/L dan kadar osmolaritas darah tinggi (295-400 mOsm/l). Gejala klinis dan laboratoris terbanyak adalah poliuri, kadar keton tinggi (>5), kadar Kalium 3,5-5 dan lekosit 10.000-20.000 u/l. Asidosis metabolik pada KAD terjadi akibat akumulasi benda keton dalam sirkulasi. Asidosis laktat juga turut berperan pada kasus yang disertai rejatan atau perfusi perifer yang buruk, gangguan fungsi jantung, gagal ginjal dan hipoksia. Asidosis akibat KAD merupakan asidosis dengan peningkatan anion gap $(7,15)$. Asidosis biasanya terkoreksi dengan pemberian insulin dan rehidrasi. Insulin mencegah pembentukan benda keton dan memfasilitasi metabolisme benda keton menjadi bikarbonat $(1,2)$. Rehidrasi mengatasi hipovolemia, memperbaiki perfusi perifer dan fungsi ginjal dan memfasilitasi ekskresi benda keton. Asidosis dipantau dengan mengukur kadar HCO3- dan/atau pH darah serta anion gap $(7,16)$.

Edema serebri timbul akibat perubahan osmolalitas intraseluler dan ekstraseluler yang cepat. Keadaan hiperglikemia dan hipertonik menyebabkan akumulasi substansi aktif secara osmotik di otak (substansi idiogenik). Molekul ini menumpuk di otak dan berfungsi melindungi otak dari pengerutan dan kehilangan cairan selama dehidrasi. Selama periode rehidrasi, osmolalitas serum menurun sedangkan osmolalitas sel masih tinggi sehingga air akan masuk ke dalam sel menyebabkan edema otak $(7,17,18)$.

Kadar natrium pada pasien KAD RSSA sangat bervariasi dari rendah, normal maupun tinggi. Kadar natrium yang bervariasi bergantung pada keseimbangan cairan. Kadar natrium serum menurun karena efek dilusi dari hiperglikemia dan peningkatan lipid serta protein dalam serum. Salah satu indikator status rehidrasi adalah dengan memantau kadar Natrium.

Secara umum kadar Natrium yang dikoreksi dengan rumus (Na+corr) tetap dalam kisaran normal yaitu 135-145 mEq/L atau perlahan-lahan menjadi normal jika pada awalnya meningkat. Na+corr yang tinggi merupakan tanda adanya dehidrasi hipertonik dan rehidrasi perlu dilakukan lebih lambat. Bila Na+corr turun dibawah nilai normal maka hal 
ini menunjukkan pemberian cairan yang terlalu cepat atau retensi air. Hal ini merupakan faktor risiko terjadinya edema serebri sehingga kecepatan infus harus dikurangi tidak lebih dari 2,0-2,5 L/m2/hari atau $1,5 \times$ rumatan atau dengan menambah konsentrasi Natrium dalam cairan rehidrasi $(1,3,7)$.

Kadar kalium pasien KAD di RSSA bervariasi. Pemberian kalium sangat penting dalam tata laksana pasien KAD. Semua pasien KAD mengalami defisit kalium akibat hilangnya kalium dari pool intraseluler. Pemberian insulin dan koreksi asidosis menyebabkan kalium masuk ke dalam sel sehingga menurunkan kadar kalium serum. Defisit kalium pada orang dewasa adalah 3-6 mEq/kgBB.

\section{DAFTAR PUSTAKA}

1. Piva JP, Czepielewskii M, Garcia PC, and Machado D. Current Perspectives for Treating Children with Diabetic Ketoacidosis. Jornal de Pediatria. 2007; 83(5): S119-127.

2. Kitabchi AE and Nyenwe EA. Hyperglycemic Crises in Patients With Diabetes Melitus: Diabetic Ketoacidosis and Hyperglycemic Hyperosmolar State. Endocrinology and Metabolism Clinics of North America. 2006; 35(4): 725-751.

3. Cokram CS. The Epidemiology of Diabetes Mellitus in the Asia-Pasific Region. Hong Kong Medical Journal. 2000; 6(1): 43-52.

4. Charfen MA and Fernandez-Frackelton M. Diabetic Ketoacidosis. Emergency Medicine Clinics of North America. 2005; 23(3): 609-628.

5. Danne T, Lange K, and Kordonouri O. New Developments in the Treatment of Type 1 Diabetes in Children. Archives of Desease in Childhood. 2007; 92(11): 1015-1019.

6. Dunger DB, Sperling MA, Acerini $\mathrm{CL}$, et al. European Society for Paediatric Endocrinology/Lawson Wilkins Paediatric Endocrine Society Consensus Statement on Diabetic Ketoacidosis in Children and Adolescent. Pediatrics. 2004; 113(2): e133-140.

7. Kirschbaum B, Sica D, and Anderson FP. Urine Electrolytes and the Urine Anion and Osmolar Gaps. Journal of Laboratory and Clinical Medicine. 1999; 133(6): 597-604.

8. Rosenbloom Al, Silverstain JH, Amemiya S, Zeitler $\mathrm{P}$, and Klingensmith. Type 2 Diabetes in Children and Adolescent. Pediatric Diabetes. 2009; 10(suppl 12): 17-32.

9. Cardwell CR, Stene LC, Joner G, et al. Birth Order and Childhood Type 1 Diabetes Risk: A Pooled Analysis of 31 Observational Studies. Int. J. Epidemiol. 2011; 40(2): 363-374.

10. White NH. Diabetic Ketoacidosis in Children.
Meskipun tidak ada data spesifik, defisit yang sama juga dialami oleh anak. Jika tidak dijumpai gangguan miksi maka sejak awal pasien sudah harus mendapat kaliumyaitu $40 \mathrm{mEq} / \mathrm{L}(\mathrm{BB}<30 \mathrm{~kg}$ ) atau $80 \mathrm{mEq} / \mathrm{L}$ (BB> $30 \mathrm{~kg}$ ). Kecepatan pemberian tidak boleh melebihi 40 $\mathrm{mEq} / \mathrm{jam}$ atau $0,3 \mathrm{mEq} / \mathrm{kg} / \mathrm{jam}$. Preparat kalium yang digunakan dapat berupa kalium klorida, kalium fosfat atau kalium asetat. Tidak ada uji klinis terkontrol yang menyatakan kelebihan salah satu preparat tersebut $(7,17,19)$. Hiperlekositosis sering terjadi pada keadaan $K A D$, walaupun tanpa disertai tanda infeksi. Hal ini disebabkan adanya peningkatan kadar katekolamin yang ada dalam sirkulasi darah $(13,19)$.

Endocrinology and Metabolism Clinics of North America. 2000; 29(4): 657-682.

11. Edge JA. UK DKA Guidelines. British Society for Paediatric Endocrinology and Diabetes. 2002; 2: 231245.

12. Wolfsdorf J, Glaser N, and Sperling MA. Diabetic Ketoacidosis in Infants, Children, and Adolescents. Diabetes Care. 2006; 29(5): 1150-1159.

13. Kayashima T, Yamaguchi K, Akiyoshi T, Nanimatsu $H$, Aragaki S, and Hosokawa T. Leukemoid Reaction Associated with Diabetic Ketoacidosis with Measurement of Plasma Levels of Granulocyte Colony-Stimulating Factor. Internal Medicine Journal. 1993; 32(11): 869-871.

14. Sperling MA. Diabetes Mellitus. In: Sperling MA (Ed). Pediatric Endocrinology 2nd edition. Philadelphia: Saunders; 2002; p. 325-353.

15. Knight AH, William DN, Ellis G, and Goldberg DM. Significance of Hyperamylasaemia and Abdominal Pain in Diabetic Ketoacidosis. British Medical Journal. 1971; 3(5872): 128-131.

16. Craig $\mathrm{ME}$, Jones TW, Silink $\mathrm{M}$, and Ping YJ. Diabetes Care, Glycemic Control and Complications in Children with Type 1 Diabetes from Asia and the Westren Pasific Region. Journal of Diabetes and It's Complication. 2007; 21(5): 280-287.

17. Umpierrez GE, Murphy MB, and Kitabachi AE. Diabetic Ketoacidosis and Hyperglicemic Hyperosmolar Syndrome. Diabetes Spectrum. 2002; 15(1): 28-36.

18. Silink M APEG Handbook on Childhood and Adolescent Diabetes the Management of Insulin-Dependent ( Type 1 ) Diabetes Mellitus (IDDM). Paramatta NSW: Australian Paediatric Endocrine Group Australia; 2006.

19. Rustama DS, Subardja D, Oentario MC, Yati NP, Satriono, dan Harjantien N. Diabetes Mellitus. Di dalam: Jose RLB (Ed). Buku Ajar Endokrinologi Anak. Jakarta: Sagung Seto; 2010; hal. 124-161. 